\title{
LINGUISTIC NOTES: ON IOTA AND COMMA
}

Nowadays, the Polish noun jota $[\text { iota }]^{1}$ is used in two literal meanings as: 1. 'the name of the letter $j$ and the corresponding sound,' and 2. 'the name of the ninth letter of the Greek alphabet $I$, r.' 2 This lexeme was defined in a completely different way in Samuel Bogumił Linde's dictionary, who in a relevant entry included only the figurative meaning (preceded by the qualifier fig.): 'The smallest dot in writing., This explication was accompanied by exemplary uses - quotations from Polish literature: 'Do ostatniej sie joty pisma petnić musza. Co do joty wypetnię twe rozkazy. Prawo jest tak święta rzecza, że i jedna jota niepowinno być odmienione. On na twe skargi, żale i sprawoty/ Nie odpowiada jednej nawet joty ${ }^{4}$ [The writings must be completed until the last dot. I will obey your commands to the letter. The law is such a sacred thing that not even one dot should be changed. He is not answering to your complaints, grievances and cases/ not even one jot].

1 This refers, of course, to a noun that is a continuation of the Greek iota, not a homonymous noun derived from the Spanish jota and meaning 'a Spanish folk dance,' which is rare in the Polish language.

2 Definitions cit. after: Uniwersalny słownik języka polskiego, ed. S. Dubisz, Vol. I: A-J, Warszawa 2003 (henceforth: Dubisz's Dictionary).

3 Stownik języka polskiego przez M. Samuela Bogumiła Linde. Wydanie drugie, poprawione i pomnożone, Vol. II: G-L, Lviv 1855 (henceforth: Linde's Dictionary). The entry jota begins with a reference to the entry $I$, there Linde writes not only about 'the ninth letter according to the Latin alphabet,' but also about the Polish consonant $j$.

${ }^{4}$ Interestingly, very similar contexts are recorded as still vivid phraseological units in contemporary lexicons, e.g. in Dubisz's Dictionary: co do joty - 'with the smallest details,' jota w jote - 'strictly, precisely, in the smallest details' and ani na jote - 'not a bit, not at all.' 
The definitions proposed in the Vilnius Dictionary are almost the same as the contemporary ones. For understandable reasons, only the order of the meanings is different: the name of the ninth letter of the Greek alphabet '(usually called je)' and the consonant $j$ of the Polish alphabet. ${ }^{5}$ What is more important, however, is that the authors of the dictionary not only register, but also reconstruct the figurative meanings of this lexeme: "fig. Nie brak ani joty, t.j. niczego" [fig. nothing is missing, not even a jot]. Secondary literal meanings can also be attributed to at least some of the examples quoted in the analysed entry (which are in part paraphrases of Linde's examples): Nie opuścił ani joty. Spamiętać, przepisać co do joty. Wypetnić rozkaz co do joty. Nie odpowiedziat mu ani na jote [He did not give up, not a bit. Remember, copy to the letter. Carry out the order to the letter. He did not reply to him, not even a word].

In the Warsaw Dictionary, in addition to identical literal meanings we find in the Vilnius Dictionary, there are also several different figurative meanings of jota: "Nie brak ani joty (= niczego). [...] Spamiętać, przepisać co do joty (= wszystko od A do Z). [...] Jota w jotę. Prz. (= kubek w kubek, kropla w kroplę, dokładnie, akuratnie, ściśle, literalnie) ${ }^{" 6}$ [Not even a jot is missing (= nothing is missing). To remember, to copy something to the letter. (= everything from A to Z). Exactly the same. Fig. (=just like, exactly, strictly, literally)].

On based on the brief lexicographic review above, it can be assumed that jota functioned in the $19^{\text {th }}$ century (as well as in the older form of) Polish language, mainly in figurative senses (this is indicated by almost all the examples found in the dictionaries), referring to those semantic aspects of the examined word which emphasised the small size of jota. Such non-literal meanings were motivated by the fact that the Greek (and also, which the dictionaries cited here do not mention, the Hebrew) graphic symbol of iota was the smallest of all graphic symbols of the letters in those alphabets. No wonder iota started to be associated more generally with something very small, with some small element, or a detail of something. In the Polish language, such an understanding of jota was popularised by the Bible in the translation by Fr. Jakub Wujek, and more precisely by the fragment of the Gospel according to St Matthew in which Jesus speaks: "Zaprawdę bowiem powiadam wam: dopóki nie przeminie niebo i ziemia, jedna jota albo jedna kreska nie odmieni się w Zakonie, aż się wszystko stanie" [For verily I say unto you, Till

5 Stownik języka polskiego [...]; do podręcznego użytku wypracowany przez Aleksandra Zdanowicza, Michała Bohusza Szyszke, Januarego Filipowicza, Walerjana Tomaszewicza, Florjana Czepielińskiego $i$ Wincentego Korotyńskiego, z udziałem Bronisława Trentowskiego. Wydany staraniem i kosztem Maurycego Orgelbranda, Vol. I: A-O, Vilnius 1861 (henceforth: the Vilnius Dictionary).

6 Słownik języka polskiego ułożony pod redakcja J. Karłowicza, A. A. Kryńskiego, W. Niedźwiedzkiego, Vol. II: H-M, Warszawa 1902 (henceforth: the Warsaw Dictionary). 
heaven and earth pass, one jot or one tittle shall in no wise pass from the law, till all be fulfilled]. ${ }^{7}$

In Norwid's writings, jota is used only 7 times $;^{8}$ importantly, not a single of these uses does actualise the literal meaning of this noun. ${ }^{9}$ The poet first used it in 1854 , in a letter written from New York to Maria Trębicka:

[...] wszelkie światto dziś jest sfałszowane i popsowało drogi swoje, i jesteśmy bliscy skończenia świata $w$ pewnej proporcji - tak jak każdy dzień ma swoją całość energii żywotnej i kończy się. Nastąpią więc wszystkie te fenomena co do joty, co do kreski, które po ukrzyżowaniu Zbawiciela nastąpiły, tylko w jakiej proporcji, to tego nikt nie wie matematycznie, jedno Ojciec, albowiem co jest kara i dopuszczeniem kary musi być od władzy, nie od wiedzy. (DW X 498) ${ }^{10}$

[...] all light today is falsified and has spoiled its own ways, and we are close to the end of the world in a certain proportion - just as every day has its whole vital energy and it ends. Thus all these phenomena will occur to the letter, to the word, which followed the Saviour's crucifixion, but in what proportion, no one knows this mathematically, only the Father; for what is the punishment and the admission of punishment must come from power, not from knowledge.

7 Biblia w przektadzie księdza Jakuba Wujka z 1599 r., transcript type "B" of the original $16^{\text {th }}$-century text and introductions by Fr. J. Frankowski, Warszawa 1999. The English version after King James Bible (Matthew 5, 18).

${ }^{8}$ Figures concerning Norwid's writings cit. after: J. PuZynina, T. Korpysz, Internetowy słownik języka Cypriana Norwida, https://slownikjezykanorwida.uw.edu.pl/ [accessed on 1 June 2019].

9 For comparison, there are only two uses of jota in Adam Mickiewicz's writings. In the first one, although the whole context has a figurative sense, the noun itself is used in the literal sense and refers to the Greek letter, while in the second one it is an element of an idiomatic expression co do joty. See Słownik języka Adama Mickiewicza, eds. K. Górski, S. Hrabec, Vol. II: H-K, WrocławWarszawa-Kraków 1968 (henceforth: the Dictionary of Mickiewicz's language).

${ }^{10}$ Quotations from Norwid's texts and references to them after: C. NorwID, Dzieła wszystkie [Complete Works], ed. S. Sawicki, Lublin 2009 (henceforth DW with Roman numerals referring to the numbers of the volumes and Arabic numerals referring to page numbers), and in the case of texts not yet included in this edition, after: C. NorwID, Pisma wszystkie [Complete Writings], compiled, edited, with introduction and critical commentaries by J. W. Gomulicki, Vols. I-XI, Warszawa 19711976 (henceforth PWsz with Roman numerals referring to the numbers of the volumes and Arabic numerals referring to page numbers). 
As it can be seen here, Norwid uses the idiomatic phrase, co do joty, meaning 'exactly the same, identical, to the letter.' It is also worth noting in the quoted fragment - due to the juxtaposition with a contextually close construction co do kreski [lit. to the stroke] - the poet reaches for intensification, which was something he often employed. ${ }^{11}$ This sequence clearly refers to the above quotation from the Gospel of St Matthew.

For the second time, the poet used the noun jota in a work created a year later, Liście o stolikach wirujacych [A Letter about the Spinning Tables]. It is characteristic that also in this case kreska [stroke] appears along with the discussed lexeme (in the sense of "the smallest element of the biblical text ${ }^{\text {" }}$ ) in the context that is another reference to the evangelical quotation:

[...] ja tak wierzę, że nie tylko to, co Pismo mówi jako myśl - zdanie, precepta, parabola, rozkaz, znak, litera, koma - ale nawet, co kreska i co jota - wszystko jest prawdą nieledwie równoważną. (PWsz VI, 624)

[...] I so believe that not only what the Scriptures say as a thought a sentence, precept, parable, command, sign, letter, coma - but even a stroke and a iota - everything is a truth that is almost equivalent.

Two other occurrences of the analysed lexeme come from the poems from the 1860s: Wczora-i-ja [Yester-and-I] and Dziennik Warszawski [Warsaw Daily]. In the former, the koma and jota that appear in a sequence no longer refer simply to some undefined small elements, but rather important, significant details that constitute the essence of the message and its true content. Failure to notice them makes it impossible to understand the poem properly which the poet describes with the metaphor of deafness: ${ }^{13}$

${ }^{11}$ Although Jadwiga Puzynina does not mention sequences among the various types of linguistic means of intensification present in Norwid's poems, she points, among others, to a more general category of concentration (see J. PuZYnInA, Problemy intensyfikacji językowej w liryce Norwida, [in:] Liryka Cypriana Norwida, eds. P. Chlebowski, W. Toruń, Lublin 2003, p. 113).

${ }^{12}$ The contextual understanding of this noun is close to one of its meanings present in the $16^{\text {th }}$ century sources: 'the smallest sign in the Holy Scriptures' (see Stownik polszczyzny XVI wieku, ed. M.R. Mayenowa, Vol. IX: iskać-już, Wrocław-Warszawa-Kraków-Gdańsk 1975).

${ }^{13}$ One cannot agree with Jack Trznadel, who in his interpretation of this poem understands koma and jota simply as 'comma' and a 'full stop' (see J. Trznadel, Czytanie Norwida. Próby, Warszawa 1978, p. 297). It is also impossible to consider Anna Kozłowska's reading proposal as right - she interprets the fragment as "a reflection on the need to pay more attention to the form of expression" (A. KozlowsKA, Jednostka wobec konwencji. Uwagi o interpunkcji w tekstach Cypriana Norwida, [in:] Tożsamość tekstu - tożsamość literatury, eds. P. Bem, Ł. Cybulski, M. Prussak, Warszawa 2016, p. 118), because despite the lexis used by Norwid and referring to the graphic aspect, it in fact concerns the content and not the form of expression. 
Och! smutna to jest i mało znajoma

Głuchota -

Gdy Słowo słyszysz - ale ginie k o m a

I jota...

(PWsz I, 334)

Oh! How is sad and little known

Is deafness -

When you hear the Word - but lose the c o m m a

And i o t a ${ }^{14}$...

In contrast, in Dziennik Warszawski, jota once again becomes a metaphorical term for each, even the tiniest element of the Bible:

Dlatego - żują klątwę, co nie zamrze,

Aż znowu święta-księga się od-modli,

Jota po jocie... i klamra po klamrze -

Podli!... bo niemi, i niemi, bo podli!

(PWsz I, 392)

That is why - they are chewing the curse, which will not fade away,

Until again they pray from the sacred-book,

Letter by letter... and clasp after clasp -

They are mean!... ...because they are dumb, and dumb, because they are mean!

Chronologically, the last three contexts containing this noun come from Norwid's correspondence.

In 1868, Norwid sent Karol Ruprecht the poem, Do publicystów Moskwy [To the Moscow publicists], accompanied by a two-sentence epistolary note:

Racz czytać śpiewem lirycznym, nie odmieniając ani joty. Ale czytać na starożytny grecki sposób. (PWsz IX, 374)

Read with lyrical singing, without changing anything, not a jot. But read in an ancient Greek way.

The poet, using the phraseology registered in $19^{\text {th }}$ century lexicons, calls here for a particularly careful reading of the sent work; a reading that respects all, even the tiniest aspects of this text. This request is even more important because Norwid was sceptical about the possibility of its proper understanding by his contemporar-

${ }^{14}$ C. Norwid, Poems, translated from the Polish by Danuta Borchardt in collaboration with Agata Brajerska-Mazur, New York 2011, p. 117. 
ies. In another letter sent shortly afterwards to Ruprecht he wrote: "Rym ulotny, który Ci posłałem, niezrozumianym będzie dla obecnych, albowiem ze wszech miar nieprzytomni i żadni" [The fleeting rhyme that I sent you will be incomprehensible to the contemporaries, for by all means they are una ware and bland] (PWsz IX, 377).

A year later, Norwid described a symptomatic scene to Zofia Węgierska:

Osiemdziesięcioletni lord Palmerston będzie dyskutował z lordem młodym, ledwo że blady porost brody mającym, a ten mu na jedną jotę swych przekonań (choćby wątpliwie ważnych) nie ustąpi... (to są $1 \mathrm{u} \mathrm{d} \mathrm{z} \mathrm{i} \mathrm{e,} \mathrm{nie} \mathrm{figurki} \mathrm{z} \mathrm{piernika!).} \mathrm{(PWsz} \mathrm{IX,} \mathrm{412)}$

The eighty-year-old Lord Palmerston will have a discussion with the young lord, who has barely got a pale beard, and this one will not give way, not a jot, to his beliefs (even if doubtfully important)... (These are p e o p l e, not gingerbread figures!).

The phrase (nie ustapić) na jedna jote [(not to give way), not a jot] is an author's modification of the idiomatic expression recorded in dictionaries: ani na jotę 'not at all.'

The last example of Norwid's use of the lexeme jota comes from 1875, from a letter to Bronisław Zaleski. What is interesting, the poet once again refers to the evangelical sequence of jota [dot] and kreska [dash]:

Otóż - że od lat kilkuset w Europie nikt ze staranniejszego wychowania i z tradycji staranniejszych nie zostawa księdzem (tylko oni bardzo bronią Kościoła żół c ią i a ne g dota mi przy herbacie wieczornej), więc stan ten przechodzi w ręce ludzi, którzy jak „rzemiosło łatwe” pełnią go. Parabola albowiem Zbawiciela o pr z y m u s z o n y c h, ab y do uczty królewskiej przystąpili, pełni się tak samo jak i każde Ewangelii słowo, kreska i jota. (PWsz X, 61)

Well - that for several hundred years in Europe nobody of more careful upbringing and with more careful traditions becomes a priest (only they defend the Church strongly w it h crudity and anecdotes at the evening tea), so this status passes down into the hands of people who perform it as an "easy craft." The Saviour's parable about th o s e forced to come to the royal feast, is being fulfilled like every word of the Gospel, dash and iota.

III

In two of the above quotations, also koma appears alongside jota. In $19^{\text {th }}$ century lexicons, this noun primarily meant (apart from 'coma' or 'tail of a comet') 
'comma' - this is the first meaning provided by the Vilnius Dictionary and the Warsaw Dictionary. ${ }^{15}$ In Norwid's writings, the noun koma appears six times, and these contexts can be divided into two groups. ${ }^{16}$

The first group comprises of literal uses. This is how one should read the wellknown fragment of the poem Rzecz o wolności stowa [On the Freedom of Speech] and one of the notes:

Dlatego to, nareszcie, wiemy doskonale,

Że choć mówi się: ,proza...”

...prozy? - nie ma wcale...

I jakże by być mogła!... skoro są periody?

Dwukropki? - komy? - pauzy - ? -

...to jest brulion Ody,

Nie napisanej wierszem... proza jest nazwiskiem,

Które - jak zechcę? - głosu odmienię przyciskiem...

(DW IV, 127)

That is why, finally, and we know this well,

That even though we say: "prose..."

... prose? - there is none at all...

And how could it be... when there are dots?

Colons? - commas? - pauses - ? -

......this is the draft of an Ode,

Not written in a poem......prose is a name,

Which - if I want - I will change with an emphasis of my voice...

[...] znaki pisarskie: koma - średnik - dwukropek - punkt - wykrzyknik - pytajnik - pauza - - są epoki śpiewnej języka spuścizną. Są nutami pieśni zaginionej w jej materiale. (PWsz VII, 392)

[...] writing marks: coma - semicolon - colon - dot - exclamation mark - question mark - pause - are the legacy of the singing tongue era. They are notes of a song lost in its material.

15 The term przecinek supplanted the previous name koma; Linde wrote in his dictionary about przecinek that it was "a new name of one of the writing marks, comma." This noun appears neither in Mickiewicz's writings nor in those by Norwid, who used to sometimes call this punctuation mark also kreska [stroke, dash], in accordance with the old tradition, established, inter alia, in Biblia Wujka.

${ }^{16}$ For comparison, the Dictionary of Mickiewicz's language registers only one, literal use of koma. 
It is worth noting here that both quotations testify to the rhetorical and intonational understanding of punctuation, still valid until about the mid- $19^{\text {th }}$ century, ${ }^{17}$ according to which a comma is "a mark of a small stop in pronunciation." ${ }^{18}$ As Feliks Przyłubski notes:

Interpunction was treated as a system of clues for modulating the voice and taking breaks, so it depended more on the temperament of the writer than on the objective logical construction of his speech. Only indirectly - as the reader was supposed to take breaks, suspend the voice, raise and lower it in order to reflect as clearly as possible every thought of the text being read - punctuation marks roughly outlined the logical and syntactic structure of language. ${ }^{19}$

And this is how the role of punctuation was described by the author of the first separate, more extensive Polish publication devoted to this issue:

[...] punctuation is not only helpful for the reader, but is even his guide: it contributes to the clarity and intelligibility of writing, guiding the reader in such a way that the incompetent person seems, like the learned man, to understand the thing being read; it indicates to him where to rest or take a break to breathe, and how much time can be taken for this; it holds the listeners' attention, and indicates the limits of meaning; and finally, it prevents the obscurity or ambiguity that sometimes arise from the way of writing. ${ }^{20}$

${ }^{17}$ Pointing out that that the first studies devoted exclusively to punctuation were written in the $19^{\text {th }}$ century (earlier remarks on this subject had appeared in grammar textbooks, such as in Onufry Kopczyński's famous works), Katarzyna Foremniak emphasises: "At that time there was also a fundamental change in the function of punctuation marks: the rhetorical-intonational punctuation, which had been binding for centuries and based on Latin principles, was gradually being transformed into punctuation determined by syntax" (O sztuce przestankowania w Polsce $i$ we Włoszech. Rozwój normy interpunkcyjnej od XVI wieku do wspótczesności, Warszawa 2014, p. 139).

${ }^{18}$ O. KopCzyŃSKI, Grammatyka dla szkót narodowych na klassę I, Vilnius 1803, p. 4. For more information on Norwid's use of the comma in such a function, see M.E. RoGowsKa, $O$ intonacyjno-retorycznej roli Norwidowskiej interpunkcji, „Studia Norwidiana” 30(2012), pp. 23-38. Having analysed several examples, the author emphasises: "The thoughtful, conscious use of punctuation allows Norwid to add to the text its voice shape" (ibid., p. 32).

19 F. PrzYŁuBski, Kilka słów o historii przecinka, „Poradnik Językowy” 1953, Issue 8, p. 11.

${ }^{20}$ F. BENTKOWSKI, O znakach przecinkowych $w$ pismie czyli znakach pisarskich, Warszawa 1830, p. 137. Bentkowski wrote about the comma: "All our grammarians, mostly foreigners, or authors teaching style rules, when they refer to placing commas, they say that comma (,) is put in a place, where there is a small stop, a small suspension of voice" (ibid., p. 2, see also p. 34). However, further he went on to add that commas mark pauses "of different length," and sometimes these signs "mark not so much a pause, but a change of voice in speech" (ibid., p. 93). 
Koma, as the name of a punctuation mark (comma), also appears in the previously quoted fragment of Liście o stolikach wirujacych [A Letter about Spinning Tables], where we can find an interesting hierarchical series of elements of the biblical text: "zdanie, precepta, parabola, rozkaz, znak, litera, koma [...] kreska [...] jota" [sentence, precept, parable, command, sign, letter, coma (...) stroke (...) iota] (PWsz VI, 624).

The second group of Norwid's use of koma are figurative uses. It should be stressed that they are heterogeneous since the contextual semantic shifts are of twofold nature.

In his poem Stawa [Fame], Norwid quotes - with a clearly ironic distance a series of views, including the one that

[...] nieśmiertelność jest komą niedzielną,

Co siedm dni prozę by przerwać bezczelną -

(PWsz I, 290)

[...] immortality is a Sunday coma,

To break the insolent prose every seven days -

Here, the metaphorical sense of koma refers not so much to a punctuation mark, but to a pause, and the break which it symbolises in writing; the poet therefore refers to the rhetorical and intonational function of the comma.

In the other two quotations - interestingly: in both koma is an element of a sequence, which more or less strongly reflects the phrase mentioned above from the Gospel of St Matthew - although the original sense is still active, the analysed lexeme designates primarily a small but important element of the text. It seems that this is how koma in the already discussed fragment of the poem Wczora-i-ja [Yesterday-and-I] should be understood, where it appears next to jota (see PWsz I, 334). This is also undoubtedly the meaning we find in a letter to Zygmunt Sarnecki of 1865 :

[...] muszę mieć swobodny spokój do tworzenia i uważania każdej komy i każdej linii - nie mając pierwej czasu śniadać i nie mając nigdy jednej ręki niewieściej, aby mi się oparła na ramieniu, zapytując: „Co? dziś robiłeś dla umarłych!”. (PWsz IX, 165)

[...] I must have a free rein and peace to create and watch out for every comma and every line - not having time for breakfast first and never having one hand of a woman leaning on my shoulder, asking: "What? were you doing today for the dead!." 
The studies on Norwid's punctuation highlight the importance that the poet attached to it, the often non-standard way of applying it, and the various functions it performed in his texts. ${ }^{21}$ This is also indirectly confirmed by the use of the nouns jota and koma extracted from the writings of the author of Assunta. Their combined analysis is not only motivated by the fact that in some contexts - despite obvious differences in their primary meanings - both have the secondary meaning of small elements of a text, but also by the fact that they sometimes appear side by side, in an intensifying sequence, which refers to the well-known biblical quotation from the Gospel of St Matthew. In almost all of the contexts mentioned above, with the use the examined lexemes, Norwid directly or indirectly stressed that the proper understanding of a message is dependent on the attitude that could be described as philological meticulousness - an attitude of particular attention (both on the part of the sender and the receiver) to all aspects of the text: to its content, but also to its form, which makes it possible to avoid the clearly negatively valued situation when "ginie koma i jota" [the coma and the iota are lost].

\section{REFERENCES}

BENTKOWsKi F., O znakach przecinkowych w pismie czyli znakach pisarskich, Warszawa 1830. Biblia w przekładzie księdza Jakuba Wujka z 1599 r., transcript type "B" of the oryginal $16^{\text {th }}$-century text and introductions by Fr. J. Frankowski, Warszawa 1999.

Снолак J., Echa nie zadanych pytań czy wyróżnione tematy (o pewnych użyciach Norwidowskiego pytajnika), [in:] Studia nad językiem Cypriana Norwida, eds. J. Chojak, J. Puzynina, Warszawa 1990, pp. 13-36.

Foremniak K., O sztuce przestankowania w Polsce i we Włoszech. Rozwój normy interpunkcyjnej od XVI wieku do współczesności, Warszawa 2014.

KoPCZYŃsKi O., Grammatyka dla szkót narodowych na klassę I, Wilno 1803.

${ }^{21}$ In addition to the studies listed above, the following should be mentioned: B. SubKo, O funkcjach łącznika w poezji Cypriana Norwida, „Studia Norwidiana” 5-6(1987-1988), pp. 85100 (this is a reprint of a sketch published earlier as a manuscript in post-conference materials: Język Cypriana Norwida. Materiały z konferencji zorganizowanej przez Pracownię Stownika Języka Norwida w dniach 4-6 listopada 1985 roku, eds. K. Kopczyński and J. Puzynina, Warszawa 1986); B. Subko, O Norwidowskiej sztuce stawiania kropki, [in:] Studia nad językiem Cypriana Norwida, eds. J. Chojak, J. Puzynina, Warszawa 1990, pp. 103-122; J. CHOJAK, Echa nie zadanych pytań czy wyróżnione tematy (o pewnych użyciach Norwidowskiego pytajnika), [in:] Studia nad językiem Cypriana Norwida, pp. 13-36; M.E. RogowsKa, Tekst Norwida jako problem edytorski $i$ interpretacyjny. Na przykładzie autografu „Do M.... - wtóry list,” „Humanistyka XXI wieku. Badania doktorantów Wydziału Polonistyki UW" 2011 Vol. 1 (2): Niezapisane [CD-ROM edition]. 
KozŁowska A., Jednostka wobec konwencji. Uwagi o interpunkcji w tekstach Cypriana Norwida, [in:] Tożsamość tekstu - tożsamość literatury, eds. P. Bem, Ł. Cybulski, M. Prussak, Warszawa 2016, pp. 115-130.

Norwid C., Dzieła wszystkie, ed. S. Sawicki, Lublin 2009-

NorwiD C., Pisma wszystkie, compiled, edited and with introduction and critical commentaries by J.W. Gomulicki, Vols. I-XI, Warszawa 1971-1976.

PuZYNina J., Problemy intensyfikacji językowej w liryce Norwida, [in:] Liryka Cypriana Norwida, ed. P. Chlebowski, W. Toruń, Lublin 2003, pp. 107-117.

PUZYNINA J., KORPYSZ T., Internetowy stownik języka Cypriana Norwida, https://slownikjezyka norwida.uw.edu.pl/ [accessed 1 June 2019].

PrzyŁubski F., Kilka stów o historii przecinka, „Poradnik Językowy” 1953, Isue 8, pp. 11-17.

RogowsKa M.E., O intonacyjno-retorycznej roli Norwidowskiej interpunkcji, „Studia Norwidiana" 30(2012), pp. 23-38.

Uniwersalny słownik języka polskiego, ed. S. Dubisz, Vol. I: A-J, Warszawa 2003.

Rogowska M.E., Tekst Norwida jako problem edytorski i interpretacyjny. Na przykładzie autografu „Do M.... - wtóry list, ”,Humanistyka XXI wieku. Badania doktorantów Wydziału Polonistyki UW" Vol. 1 (2) 2011: Niezapisane [CD-ROM edition].

Słownik języka Adama Mickiewicza, eds. K. Górski, S. Hrabec, Vol. II: H-K, Wrocław-Warszawa-Kraków 1968.

Stownik języka polskiego [...] do podręcznego użytku wypracowany przez Aleksandra Zdanowicza, Michała Bohusza Szyszke, Januarego Filipowicza, Walerjana Tomaszewicza, Florjana Czepielińskiego i Wincentego Korotyńskiego, z udziatem Bronisława Trentowskiego. Wydany staraniem i kosztem Maurycego Orgelbranda, Vol. I: A-O, Wilno 1861.

Słownik języka polskiego przez M. Samuela Bogumiła Linde, wydanie drugie, poprawione i pomnożone, Vol. II: G-L, Lwów 1855.

Słownik języka polskiego, eds. J. Karłowicz, A.A. Kryński, W. Niedźwiedzki, Vols. II: H-M, Warszawa 1902.

Stownik polszczyzny XVI wieku, ed. M.R. Mayenowa, Vol. IX: iskać - już, Wrocław-Warszawa-Kraków-Gdańsk 1975.

SubKo B., O funkcjach łącznika w poezji Cypriana Norwida, „Studia Norwidiana” 5-6 (19871988), pp. 85-100.

Subko B., O Norwidowskiej sztuce stawiania kropki, [in:] Studia nad językiem Cypriana Norwida, eds. J. Chojak, J. Puzynina, Warszawa 1990, pp. 103-122.

Trznadel J., Czytanie Norwida. Próby, Warszawa 1978.

\title{
LINGUISTIC NOTES: ON IOTA AND COMMA
}

\author{
S u m m a r y
}

In Norwid's writings, the nouns koma [comma] and jota [iota] that literally mean: 'comma' and 'the ninth letter of the Greek alphabet' or 'the Polish letter and consonant $\mathrm{j}$,' respectively, in the vast majority of cases have secondary, figurative meanings - in particular, when they are 
elements of idiomatic expressions, but also in some other contexts they usually refer to some small elements of a text. It is symptomatic that a large part of Norwid's usages more or less directly refer to the well-known biblical quotation from the Gospel of Matthew, which in King James Version reads: "For verily I say unto you, till heaven and earth pass, one jot or one tittle shall in no wise pass from the law, till all be fulfilled."

Norwid's use of comma and iota analysed in this article indirectly confirms the importance that the poet attached not only to the graphic layout and punctuation, or more generally to the formal aspects of the texts, but also to their proper, profound understanding.

Key words: Cyprian Norwid; spelling; punctuation; comma; iota; intensification.

Translated by Rafat Augustyn

TOMASZ KorPysZ - doctor habilitatus, assistant professor at the Institute of Polish Philology, Faculty of Humanities of the Cardinal Stefan Wyszyński University in Warsaw; head of the Department for the Dictionary of Cyprian Norwid's Language at the Faculty of Polish Studies, University of Warsaw; e-mail: t.korpysz@uksw.edu.pl 